\title{
STUDI AKSESIBILITAS PADA FASILITAS PENDIDIKAN SISWA TUNADAKSA DI SDLB-D NEGERI BENDO BLITAR
}

\author{
Whisang Geni ${ }^{1}$, Sri Hesti Heriwati ${ }^{2}$ \\ ${ }^{1}$ Program Studi S-1 Desain Interior \\ Fakultas Seni Rupa dan Desain Institut Seni Indonesia (ISI) Surakarta \\ E-mail: Whisang_lpm@yahoo.com \\ ${ }^{2}$ Program Studi S-1 Desain Interior \\ Fakultas Seni Rupa dan Desain Institut Seni Indonesia (ISI) Surakarta
}

\begin{abstract}
ABSTRAK
Artikel berisi tentang kajian Studi Kasus Tentang Desain Penerapan Aksebilitas dan Fasilitas Pendidikan Siswa Tunadaksa di SDLB-D Negeri Bendo Kota Blitar. Tugas Akhir: Jurusan Desain Interior. Fakultas Seni Rupa dan Desain Institut Seni Indonesia Surakarta. Peneliti yang digunakan metodologi penelitian kualitatif, data yang dikumpulkan memiliki arti lebih daripada hanya sekedar angka atau ergonomi. Penelitian kualitatif menekankan pada analisis induktif, teori yang dikembangkan di mulai di lapangan studi dari data yang terpisah-pisah yang saling berkaitan. Data atau informasi yang dikumpulkan dan dikaji dari beragam sumber data. Pada proses pengumpulan data selalu diikuti reduksi data dan sajian data. Hasil penelitian yang berupa catatan lapangan yang terdiri dari bagian diskripsi dan refleksinya adalah data yang telah digali dan dicatat
\end{abstract}

Kata kunci : Aksesibilitas, Ergonomi, Interior

\section{ABSTRACT}

The article contains a review of Case Study About Application Accessibility Design and Education Facilities Student-D SDLB Quadriplegic in Blitar City State Bendo. Final: Interior Design Department. Faculty of Art and Design Art Institute of Indonesia Surakarta. Researchers used qualitative research methodology, data collected means more than just numbers or ergonomics. Qualitative research emphasizes the inductive analysis, the theory developed at the start in the field of study of the data separate interrelated. Data or information collected and studied from a variety of data sources. In the data collection process is always followed by data reduction and data presentation. The results of research in the form of field notes which consists of the description and reflection is data that has been excavated and recorded

Keywords: Accessibility, Ergonomics, Interior 


\section{PENDAHULUAN}

Kota Blitar adalah kota yang terletak di bagian selatan Provinsi Jawa Timur, Indonesia. Terletak sekitar seratus enam puluh tujuh kilometer sebelah barat daya Surabaya dan delapan puluh kilometer sebelah barat kota Malang. Kota Blitar terkenal sebagai tempat dimakamkannya presiden pertama republik Indonesia. Pada saat ini kota Blitar sedang dalam upaya memajukan sektor pendidikan. Hal ini tampak dalam strategi Dinas Pendidikan kota Blitar yaitu upaya untuk pemerataan pendidikan gratis untuk semua jenjang pendidikan dengan program SPP gratis dan sarana angkutan sekolah gratis yang dibiayai oleh empat puluh enam persen APBN kota Blitar, adanya program rintisan wajib belajar dua belas tahun, pembagian perlengkapan sekolah gratis. Dalam memajukan pendidikan di kota Blitar guna mendukung program pemerintah tentang wajib belajar 12 tahun, tentunya sudah menjadi hak bagi seluruh anak usia sekolah yaitu anak usia 6 - 18 tahun untuk mendapatkan fasilitas pendidikan yang memenuhi persyaratan guna mendukung proses pembelajaran, termasuk juga dengan anak anak yang berkebutuhan khusus (disabilitas).

Anak Berkebutuhan Khusus (ABK) adalah anak yang dalam proses pertumbuhan atau perkembangan mengalami kelainan atau penyimpangan fisik, mental-intelektual, sosial dan atau emosional dibanding dengan anak anak lain seusianya, sehingga mereka memerlukan pelayanan pendidikan khusus. Kutipan diatas menjelaskan bahwa anak berkebutuhan khusus membutuhkan pelayanan pendidikan yang khusus. Fasilitas pendidikan untuk anak berkebutuhan khusus merupakan hal pokok dalam wujud pelayanan pendidikan anak berkebutuhan khusus. Kajian mengenai fasilitas pendidikan bagi anak berkebutuhan khusus menjadi suatu topik yang menarik untuk diperhatikan, khususnya bagi mahasiswa dan praktisi di bidang desain interior. Karena penyandang disabilitas mempunyai permasalahan tersendiri terkait dengan cacat fisik ataupun ganguan fungsi-fungsi kognitif yang membuat mereka mempunyai kebutuhan yang khusus pula terkait dengan alat bantu dan fasilitas pendidikan. Perbedaan inilah yang membuat para desainer interior harus belajar lebih banyak lagi mengenai keterbatasan kaum disabilitas, dan terwujudnya suatu interior yang baik dapat membantu mereka dalam menjalani proses kegiatan belajar dengan nyaman. Mencapai tujuan persamaan hak anak berkebutuhan khusus pemerintah mengupayakan suatu satuan pendidikan/ lembaga pendidikan yang sesuai dengan kekhususannya atau lebih dikenal dengan Sekolah Luar Biasa.

Sekolah Luar biasa dibagi menjadi beberapa spesifikasi yaitu SLB bagian A untuk Tunanetra, SLB bagian B untuk Tunarungu, SLB bagian C untuk Tunagrahita, SLB bagian D untuk Tunadaksa, SLB bagian E untuk Tunalaras, dan SLB bagian G untuk cacat ganda. Pengelompokan kategori ini digunakan untuk mempermudah pelaksanaan penyelenggaraan pendidikan yang sesuai dengan kekhususan obyek yang ditangani yaitu siswa pada khususnya, terkait dengan sistem penyelenggaraan pendidikan dan kebutuhan fasilitasnya. Batasan tentang pengertian disabilitas yang terlalu luas membuat banyak sekali kebutuhan fasilitas khusus yang didesain dan disesuaikan dengan kebutuhan yang khusus pula. Hal utama yang menjadi tolak ukurnya yaitu berbagai macam ketidakmampuan fisik maupun kurangnya intelegence quotient, ataupun gangguan fungsi kognitif lainnya pada setiap kelompok bagian SLB.

Fungsi kognitif adalah merupakan aktivitas mental secara sadar seperti berpikir, mengingat, belajar dan menggunakan bahasa. Studi kasus ini akan dibatasi pada pembahasan 
mengenai aksesibilitas dan fasilitas pendidikan pada penyandang disabilitas Tunadaksa yang dikelompokkan pada SLB D, di SDLB D Negeri Bendo kota Blitar. Pengambilan objek penelitian SDLB Negeri Bendo ini karena, sekolah dasar mempunyai peran dasar sebagai pondasi dalam pendidikan atau sebagai awal program wajib belajar 12 tahun. Penulis mengambil Tunadaksa sebagai objek pembahasannya karena Tunadaksa adalah individu yang memiliki gangguan gerak yang disebabkan oleh kelainan neuromuskular dan struktur tulang yang bersifat bawaan, sakit atau akibat kecelakaan, termasuk amputasi, polio, dan lumpuh. Tingkat gangguan pada Tunadaksa dapat dibagi menjadi tiga yaitu gangguan ringan yang memiliki keterbatasan dalam melakukan aktivitas fisik tetapi masih dapat ditingkatkan melalui terapi, gangguan sedang yaitu memiliki keterbatasan motorik dan mengalami gangguan koordinasi sensorik.

\section{Batasan Masalah}

Studi Aksesibilitas pada Fasilitas Belajar Siswa Tunadaksa di SDLB Negeri Bendo ini memiliki cakupan yang terlalu luas, untuk itulah perlu adanya pembatasan masalah yang akan diteliti. Adapun pembatasan masalah yang pada studi ini adalah penerapan aksesibilitas dan fasilitas belajar siswa tunadaksa dengan responden siswa kelas 6 SDLB Negeri Bendo, dengan obyek yang berkaitan dengan penelitian yaitu aksesibilitas untuk siswa dan fasilitas belajar yang ada di kelas dan fasilitas lorong Toilet siswa. Pembatasan masalah ini dipilih untuk membatasi fokus penelitian sesuai dengan latar belakang penelitian ini yaitu persamaan hak anak akan fasilitas pendidikan.

\section{Landasan Teori}

Landasan teori merupakan berbagai teori yang relevan yang digunakan untuk menjelaskan variabel yang akan diteliti dan sebagai dasar untuk memberi jawaban sementara tehadap rumusan masalah yang diajukan (hipotesis), dan penyusunan instrumen penelitian. Pokok bahasan dari penelitian ini adalah untuk menganalisa aksesibilitas dan fasilitas belajar yang telah disediakan oleh SDLB Negeri Bendo, oleh karena itu sangat penting untuk mengetahui pengertian dari istilah yang dipakai dalan judul penelitian ini

\section{Pengertian Aksesibilitas}

Menurut pengertian dalam Peraturan Menteri Pekerjaan Umum No 30 tahun 2006 tentang Pedoman Teknis Fasilitas dan Aksesibilitas pada Bangunan dan Lingkungan, Dijelaskan pengertian Aksesibilitas adalah Kemudahan yang disediakan bagi semua orang termasuk Penyandang Cacat dan lansia guna mewujudkan kesamaan dalam segala aspek kehidupan, sedangkan Fasilitas adalah semua atau sebagian dari kelengkapan prasarana dan sarana pada bangunan gedung dan lingkungannya agar dapat diakses dan dimanfaatkan oleh semua orang termasuk penyandang cacat dan lansia. Penelitian ini yang dimaksudkan dengan aksesibilitas adalah kemudahan yang disediakan berupa akses atau jalur khusus bagi siswa Tunadaksa, guna mempermudah mobilitas siswa Tunadaksa saat mengikuti kegiatan pembelajaran di sekolah, yang dimaksud dengan fasilitas belajar dalam penelitian ini adalah kelengkapan sarana dan prasarana yang membantu dalam proses belajar-mengajar, khususnya sarana dan prasarana yang membantu kegiatan belajar siswa Tunadaksa di SDLB Negeri Bendo.

\section{Teori Ergonomi dan Antropometri.}

Agar dapat menilai secara objektif kenyamanan siswa yang menjadi acuan dalam penelitian ini, maka diperlukan beberapa teori yang erat hubunganya dengan kenyamanan. 
Istilah ergonomi berasal dari bahasa Latin yaitu ergon (kerja) dan nomos (hukum alam) dan dapat didefinisikan sebagai studi tentang aspek - aspek manusia dalam lingkungan kerjanya yang ditinjau secara anatomi, fisiologi, psikologi, engineering, manajemen dan desain perancangan. Ergonomi berkenaan pula dengan optimasi, efisiensi, kesehatan, keselamatan dan kenyamanan manusia di tempat kerja, di rumah dan tempat rekreasi. Di dalam ergonomi dibutuhkan studi tentang sistem dimana manusia, fasilitas kerja dan lingkungannya saling berinteraksi dengan tujuan utama yaitu menyesuaikan suasana kerja dengan manusianya

Pengertian Antropometri berasal dari kata antropos dan metricos Antropos berarti manusia dan Metricos berarti ukuran. Antropometri adalah ukuran-ukuran tubuh manusia secara alamiah baik dalam melakukan aktivitas statis (ukuran sebenarnya) maupun dinamis (disesuaikan dengan pekerjaan).

\section{Metode Penelitian}

Metode penelitian pada dasarnya merupakan cara ilmiah untuk mendapatkan data dengan tujuan dan kegunaan tertentu. Berdasarkan hal tersebut terdapat empat kata kunci yang perlu diperhatikan yaitu cara ilmiah, data, tujuan dan kegunaan. Metode penelitian merupakan cara ilmiah untuk mendapatkan data dengan tujuan dan kegunaan tertentu, cara ilmiah berarti kegiatan penelitian didasarkan pada ciri-ciri keilmuan, seperti rasional, empiris, dan sistematis. Rasional berarti kegiatan penelitian dilakukan dengan cara-cara yang masuk akal, sehingga terjangkau oleh daya nalar manusia. Empiris berarti cara yang dilakukan dapat diamati oleh indera manusia, sehingga orang lain dapat mengetahui dan mengamati cara-cara yang digunakan. Sistematis berarti proses yang digunakan dalam penelitian itu dengan menggunakan langkah-langkah yang bersifat logis.

\section{1) Pendekatan dan Jenis Penelitian Kualitatif}

Studi ini akan diteliti aksesibilitas dan fasilitas belajar SDLB D Negeri Bendo dan pengaruhnya terhadap kenyamanan belajar siswa Tunadaksa, oleh karena itu akan dipilih metode penelitian kualitatif deskriptif. Penelitian deskriptif adalah penelitian yang berusaha

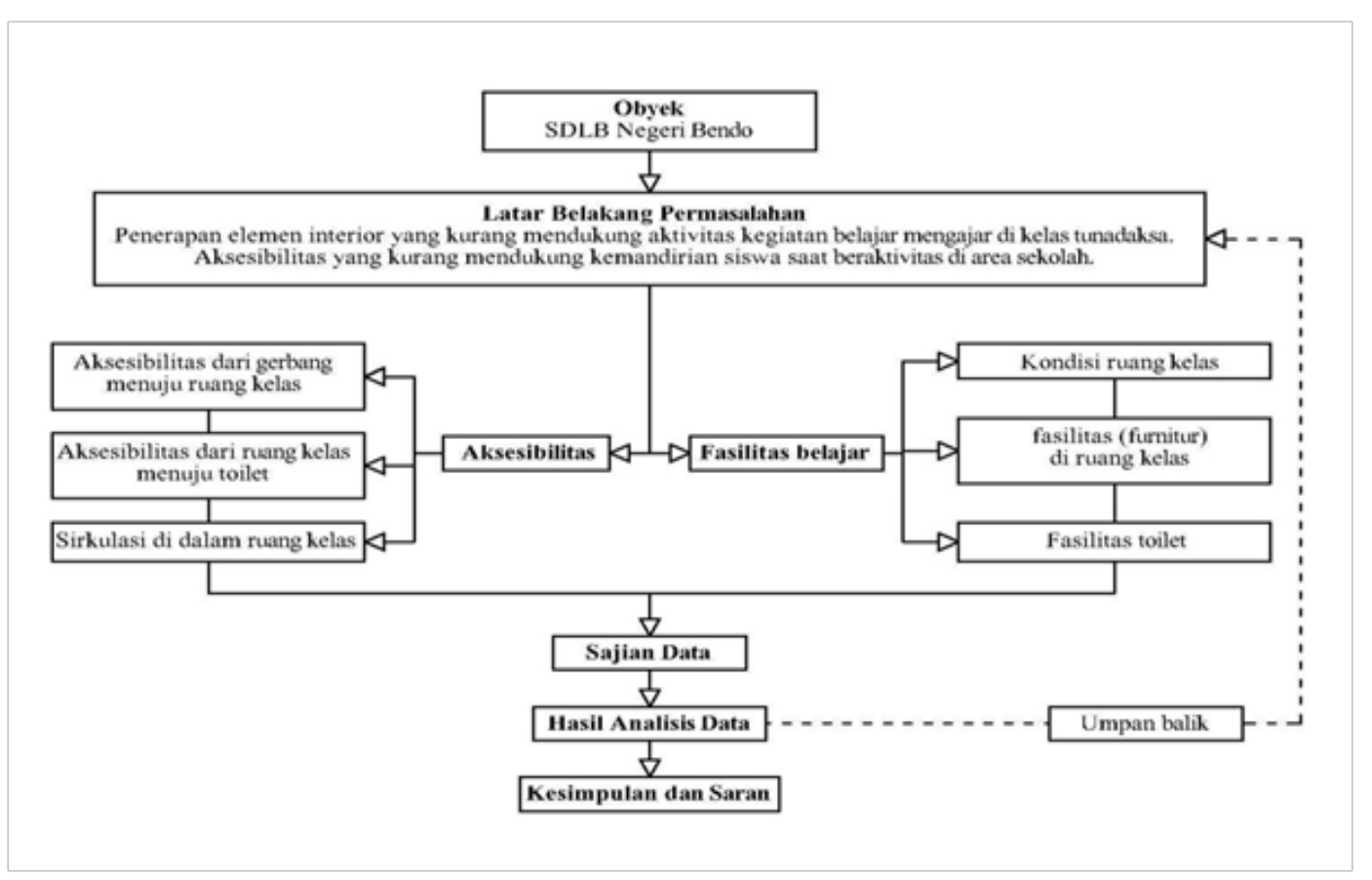


mendiskripsikan suatu gejala, peristiwa, kejadian yang terjadi pada saat sekarang. Penelitian ini adalah penelitian kualitatif deskriptif dengan studi kasus. Studi Kasus adalah suatu penyelidikan tentang individu, dan atau unit sosial yang dilakukan secara mendalam dengan menemukan semua variabel penting tentang perkembangan individu atau unit sosial yang diteliti. Maka dalam penelitian ini dimungkinkan untuk ditemukannya hal-hal tidak terduga yang kemudian dapat digunakan untuk membuat hipotesis.

\section{2) Bagan Kerangka Pikir Penelitian}

\section{Pembahasan}

Aksesibilitas didefinisikan suatu ukuran kenyamanan atau kemudahan mengenai cara lokasi tata guna lahan berinteraksi satu sama lain dan mudah atau susah-nya lokasi tersebut dicapai melalui sistem jaringan transportasi. Setiap lokasi geografis yang berbeda memiliki tingkat aksesibilitas yang berbeda hal ini disebabkan perbedaan kegiatan dari masing-masing tata guna lahan. Aksesibilitas berdasarkan tujuan dan kelompok sosial, aksesibilitas menyediakan ukuran kinerja antara tata guna lahan dengan sistem transportasi. Penghuni perumahan lebih tertarik dengan aksesibilitas menuju tempat kerja, sekolah, toko, pelayanan kesehatan dan tempat rekreasi. Aksesibilitas secara sederhana dapat dinyatakan dengan jarak. Jika suatu tempat berdekatan dengan tempat lainnya, dikatakan aksesibilitas antara kedua tempat tersebut tinggi. Sebaliknya jika berjauhan aksesibilitas antara keduanya rendah. Selain jarak dan waktu, biaya juga merupakan beberapa indikator aksesibilitas. Apabila antar kedua tempat memiliki waktu tempuh yang pendek maka dapat dikatakan kedua tempat itu memiliki aksesibilitas yang tinggi. Biaya dapat menunjukkan tingkat aksesibilitas.
Penelitian ini aksesibilitas yang dimaksud adalah bagaimana kemudahan akses jalan menuju kelas, jalan menuju toilet bagi siswa-siswa Tunadaksa yang mempunyai keterbatasan fisik. Setelah melakukan observasi di SDLB Bendo maka didapatkan data akses dari gerbang menuju ruang kelas melewati sebuah lapangan yang cukup luas, lalu naik ke teras kelas, di sini hanya ada sebuah ramp untuk pengguna kusi roda, setelah itu naik ke teras depan kelas yang mempunyai lebar $180 \mathrm{~cm}$ yang selanjutnya menuju ke pintu kelas masing-masing. Akses menuju lavatory atau toilet dimudahkan dengan penyamaan level lantai yang dibuat sama tinggi atau rata dengan teras kelas, yang selanjutnya masuk menuju lorong selebar 110 $\mathrm{cm}$ menuju pintu toilet.
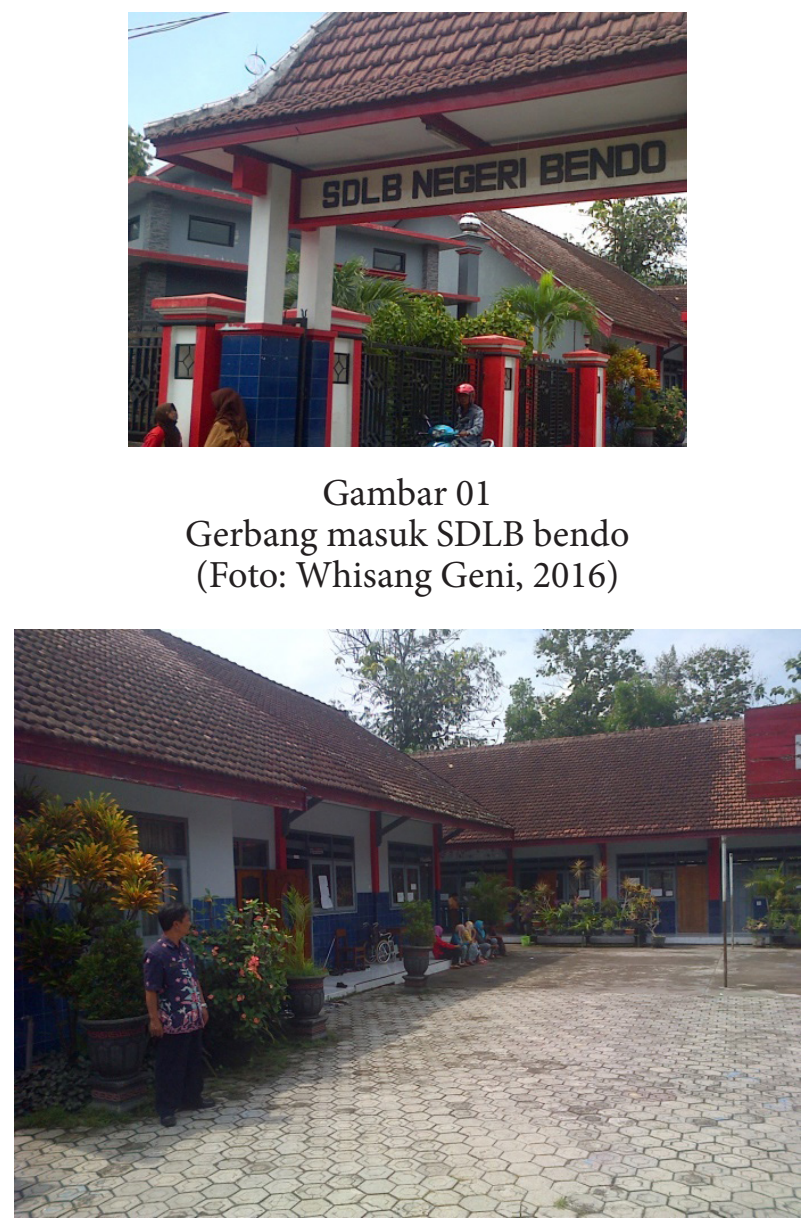

Gambar 02 
PENDHAPA, Jurnal Ilmiah Pengkajian \& Penciptaan Seni Rupa dan Desain

Akses menuju kantor guru melewati lapangan depan (Foto: Whisang Geni, 2016)

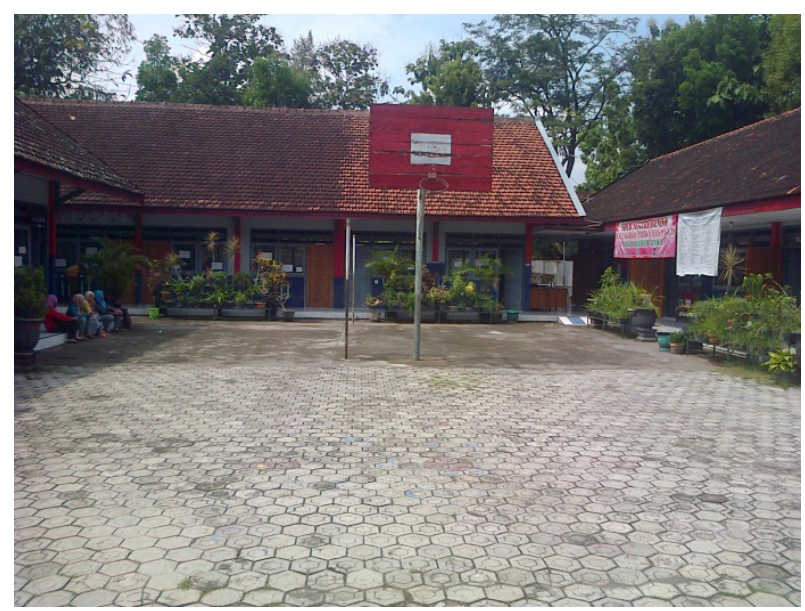

Gambar 03

Akses menuju ruang kelas melewati lapangan (Foto: Whisang Geni, 2016)
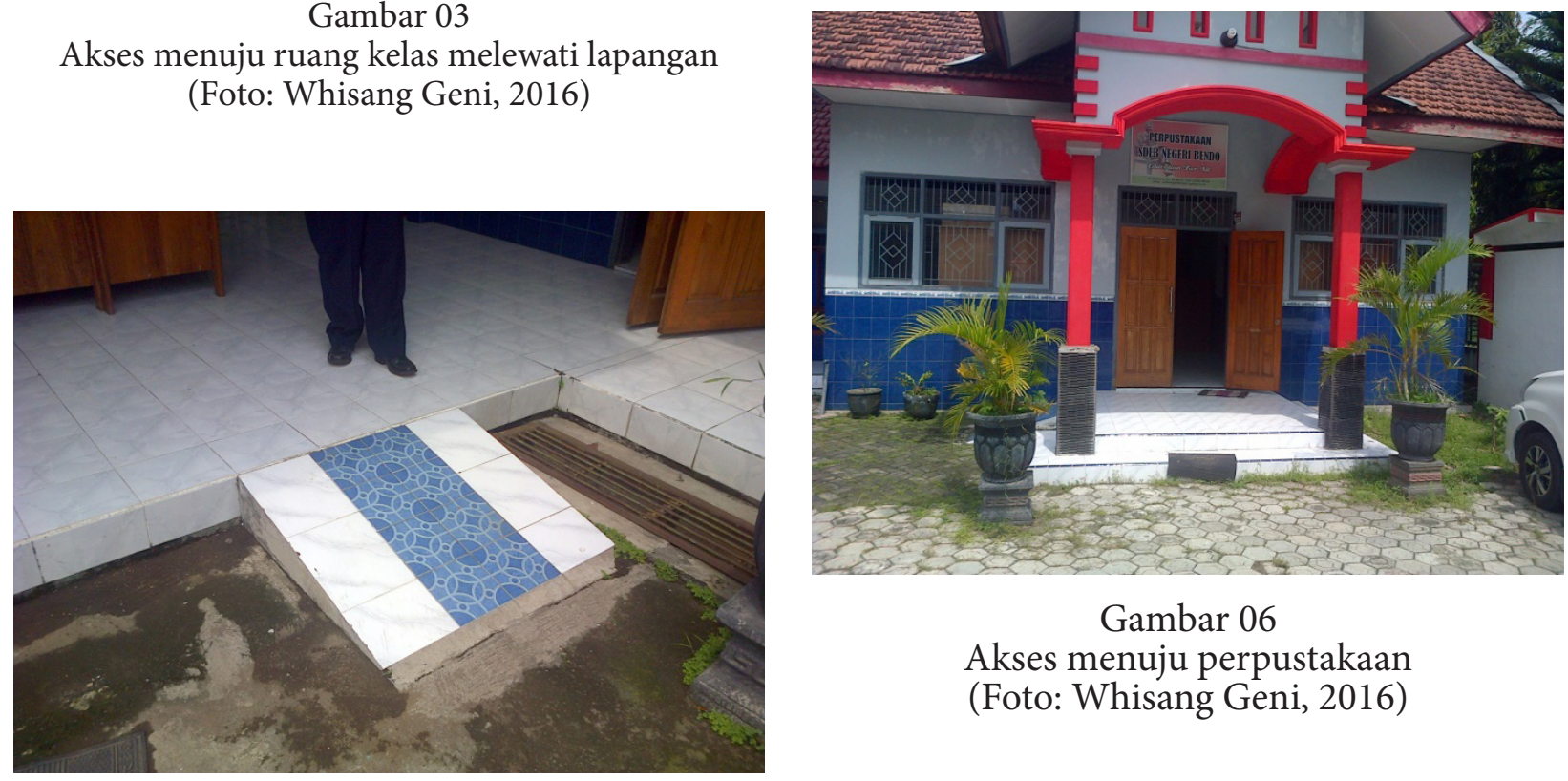

Gambar 06

Akses menuju perpustakaan

(Foto: Whisang Geni, 2016)

Gambar 04

Akses dari lapangan menuju teras kelas

(Foto: Whisang Geni, 2016) 


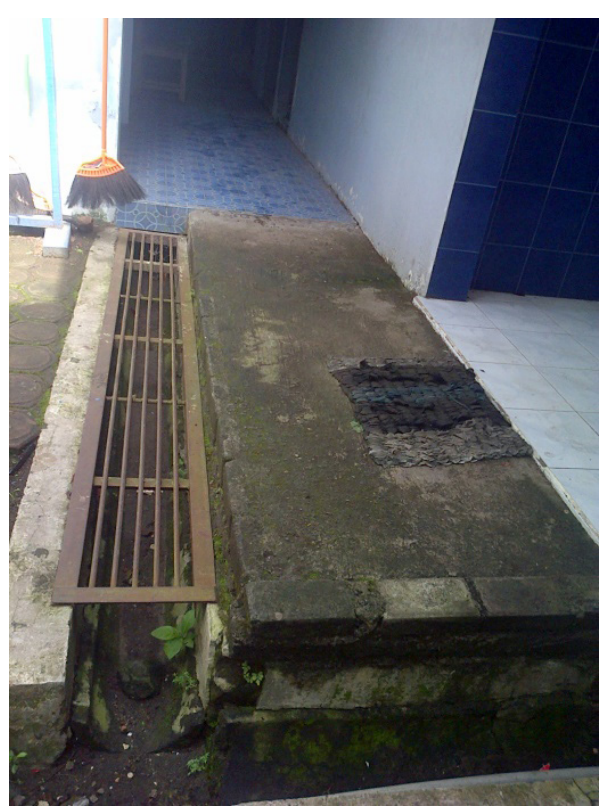

Gambar 07

Akses menuju lavatory / toilet

(Foto: Whisang Geni, 2016)

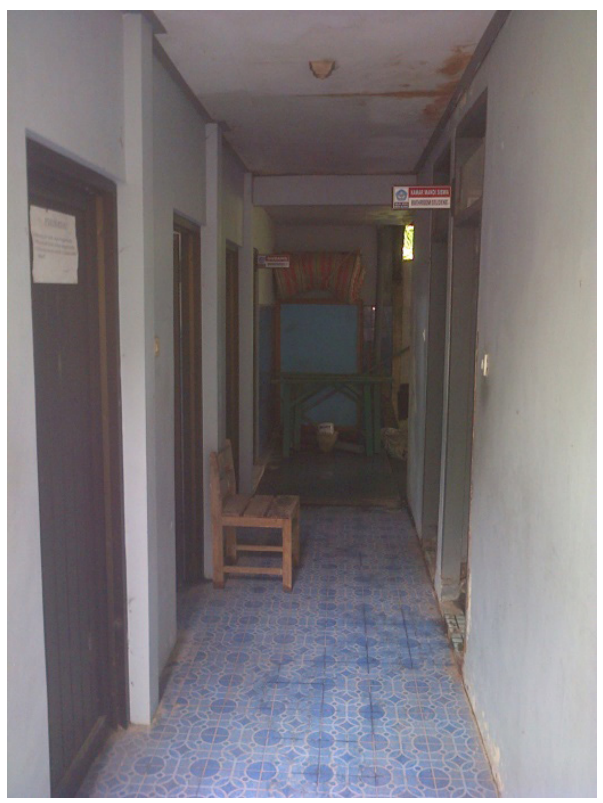

Gambar 08

Akses menuju lavatory / toilet siswa

(Foto: Whisang Geni, 2016)
Pengumpulan data yang diperoleh dan reduksi data, dapat ditemukan beberapa permasalahan mengenai aksesibilitas dan fasilitas belajar. Permasalahan-permasalahan tersebut akan dikelompokan untuk mempermudah pembahasan pada masing-masing permasalahan

Setiap berangkat ataupun pulang sekolah siswa SDLB Bendo selalu melewati akses dari gerbang menuju ruang kelas. Aksebilitas tanah lapangan yang berpasir dengan penutup tanah berupa paving block, kemudian melewati teras kelas yang memiliki level lantai lebih tinggi $20 \mathrm{~cm}$ dan selanjutnya memasuki ruang kelas masing-masing. Permasalahan yang sering terjadi adalah siswa Tunadaksa tidak bisa secara mandiri bermobilisasi melewati bagian akses ini. Dalam observasi ditemukan bahwa siswa Tunadaksa seringkali terlihat dituntun atau didorong oleh orang tua siswa atau guru dan staf SDLB Negeri Bendo melewati lapangan yang mempunyai jarak cukup jauh menuju ruang kelas. Tanjakan atau ramp yang menjadi penghubung naikan level lantai menuju teras yang berupa lantai miring dengan penutup lantai keramik membuat siswa Tunadaksa yang memakai kursi roda tidak bisa secara mandiri melewatinya, dalam observasi ditemukan seringkali siswa harus didorong untuk menaiki ataupun menuruni akses ini. Teras di depan kelas sendiri memiliki lebar $230 \mathrm{~cm}$ di sepanjang depan kelas, tidak adanya pembatas pada ujung lantai teras berpeluang membahayakan siswa yang memakai kursi roda, mengingat level lantai teras lebih tinggi $20 \mathrm{~cm}$, walaupun selama ini belum pernah terjadi permasalahan terkait dengan tidak adanya pembatas teras tersebut. Akses masuk ke ruang kelas siswa melewati akses dari teras ke ruang kelas berupa pintu masuk ke kelas dengan lebar $90 \mathrm{~cm}$. 


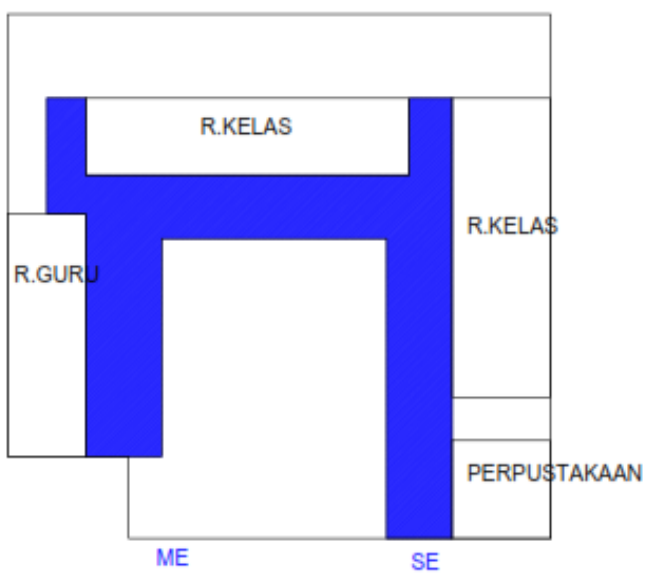

Gambar 09.

Denah Sekolah SDLB D Bendo

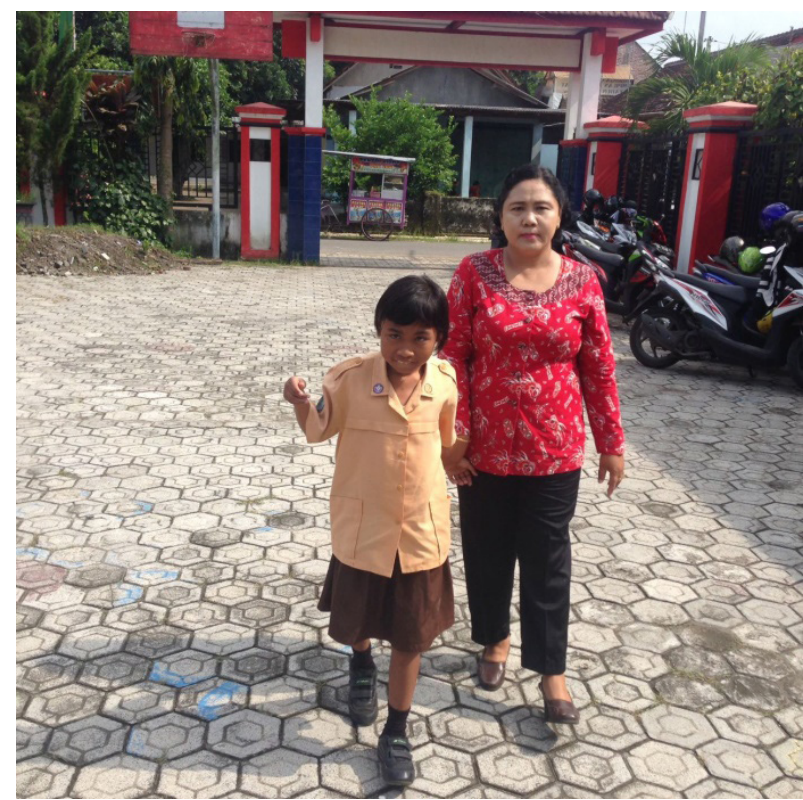

Gambar 10

Siswa responden A dibantu saat melewati lapangan menuju ke ruang kelas

(Foto: Whisang Geni, 2016)

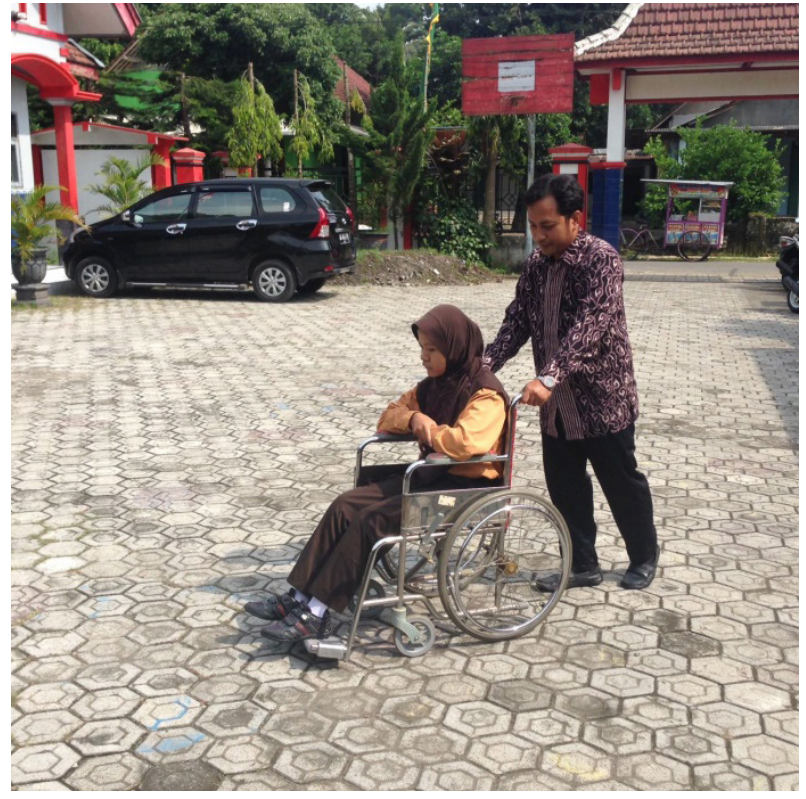

Gambar 11

Siswa responden B didorong saat melewati lapangan menuju ke ruang kelas

(Foto: Whisang Geni, 2016)

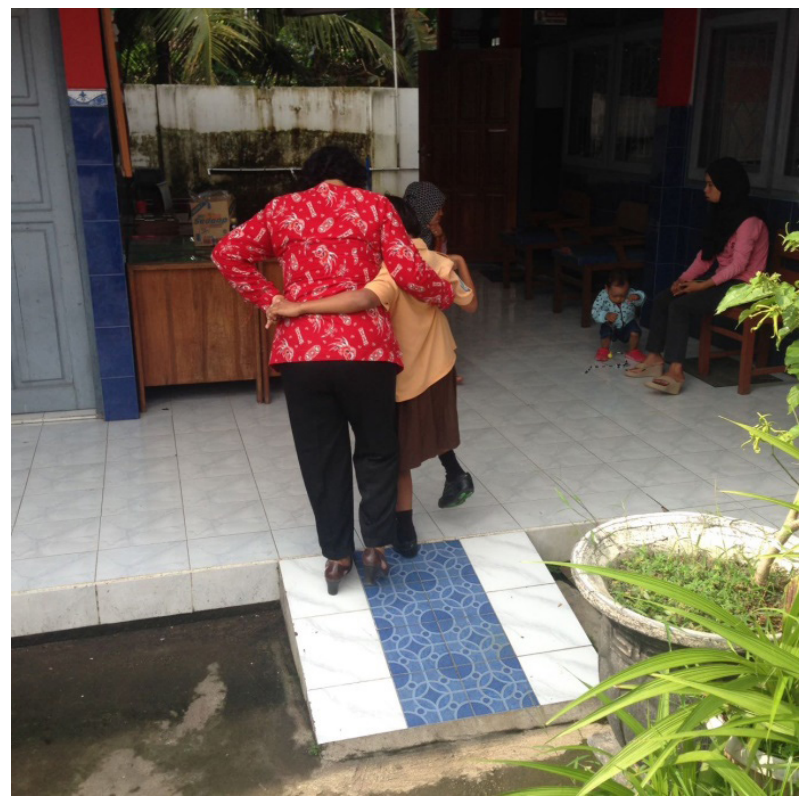

Gambar 12

Siswa responden A dipapah saat melewati Ramp menuju ke ruang kelas

(Foto: Whisang Geni, 2016) 


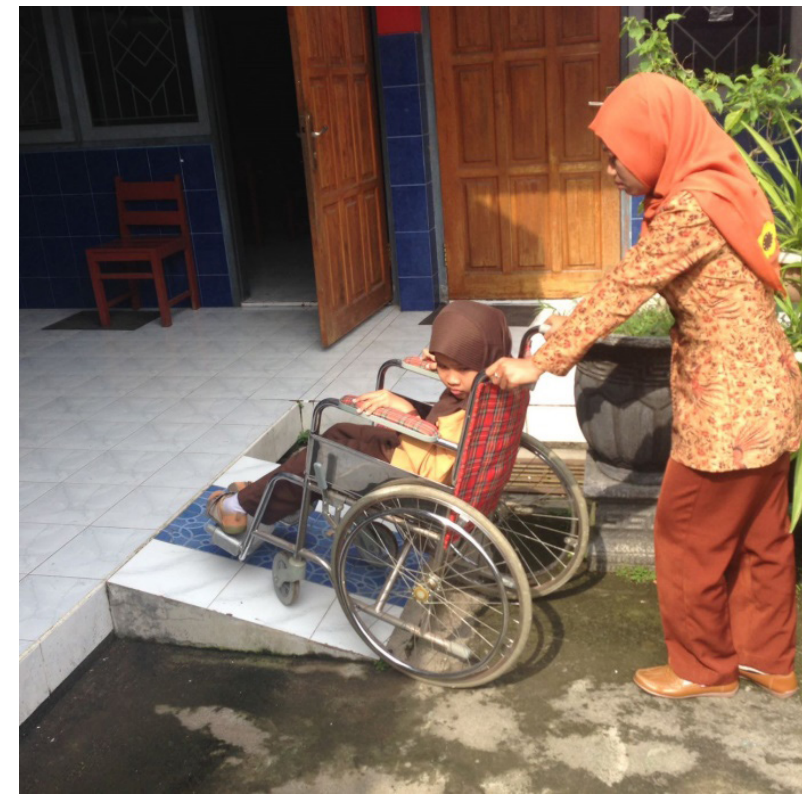

Gambar 13

Siswa responden C didorong saat melewati Ramp menuju ke ruang kelas

(Foto: Whisang Geni, 2016)

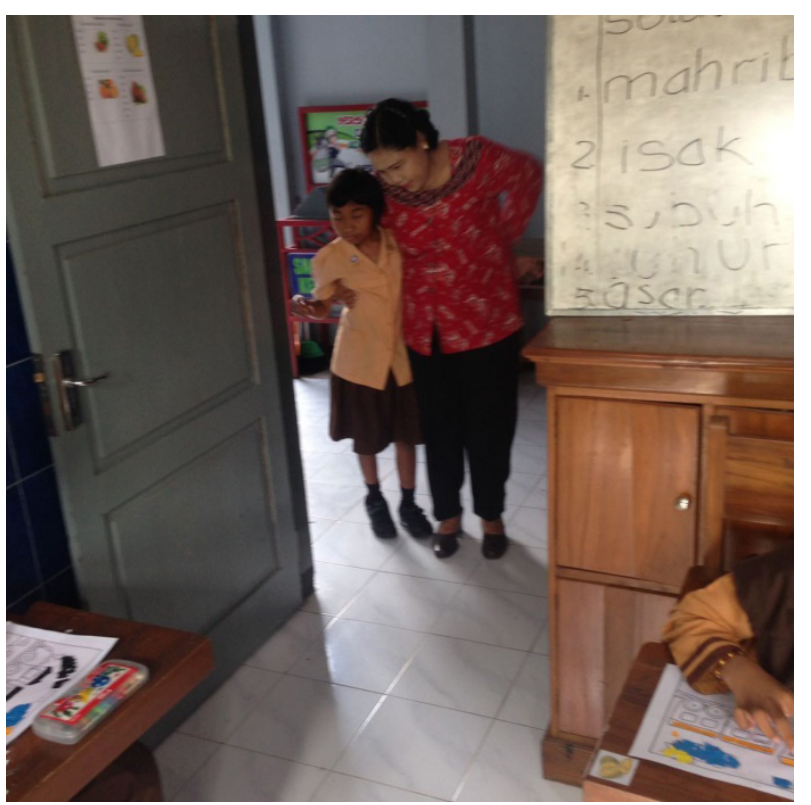

Gambar 14

Siswa responden $\mathrm{C}$ dipapah saat memasuki ruang kelas (Foto: Whisang Geni, 2016)

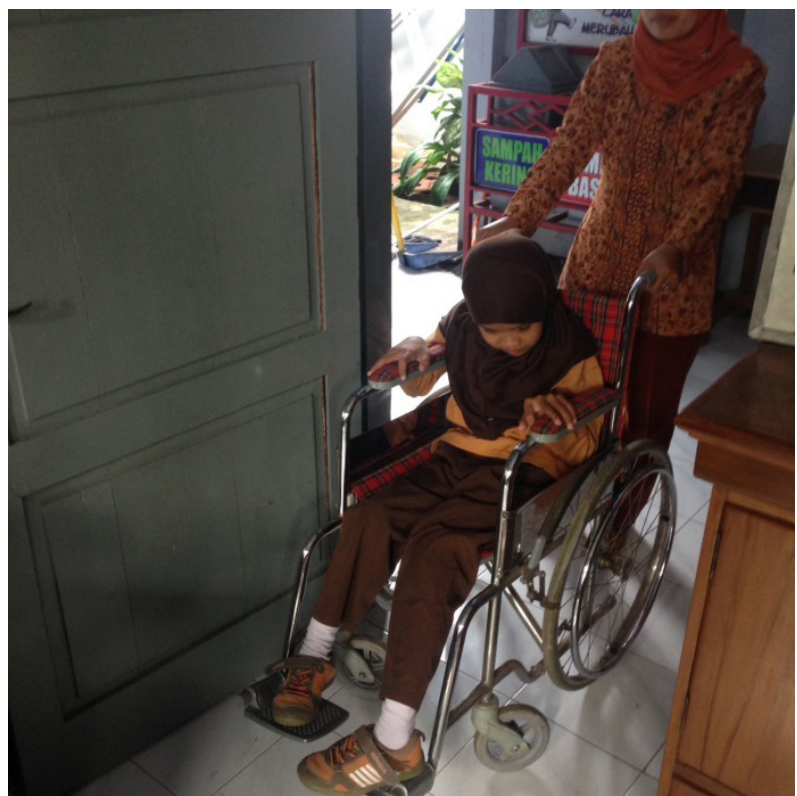

Gambar 15

Siswa responden $\mathrm{C}$ didorong saat melewati pintu ruang kelas

(Foto: Whisang Geni, 2016)

\section{Hasil Analisis}

Penerapan Aksesibilitas, Pemenuhan Standar Ergonomi dan Antropometri dan Pengaruhnya Terhadap Kenyamanan Siswa

Hasil penelitian yang telah dipaparkan sebelumnya, penerapan aksesibilitas di SDLB Negeri Bendo ini masih memiliki beberapa kekurangan yaitu seperti pada tabel berikut: 


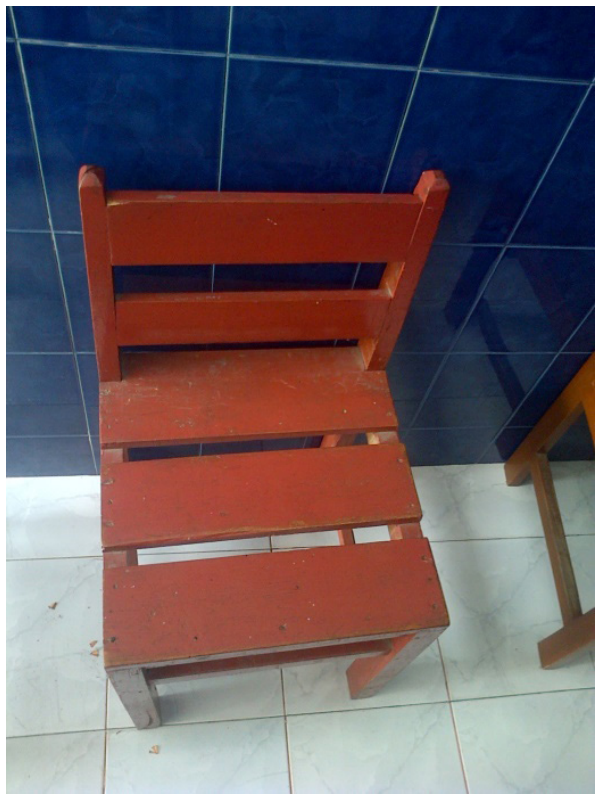

Gambar 16

Kursi belajar

(Foto: Whisang Geni, 2016)

\begin{tabular}{|c|c|c|}
\hline Panjang & Lebar & Tinggi \\
\hline $45 \mathrm{~cm}$ & $40 \mathrm{~cm}$ & $80 \mathrm{~cm}$ \\
\hline
\end{tabular}

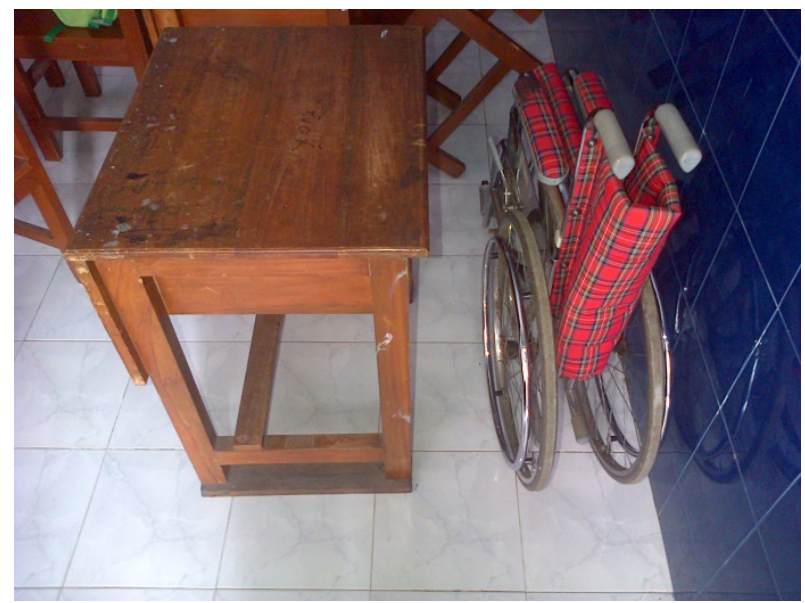

Gambar 17

Meja khusus bagi pengguna kursi roda (Foto: Whisang Geni, 2016)

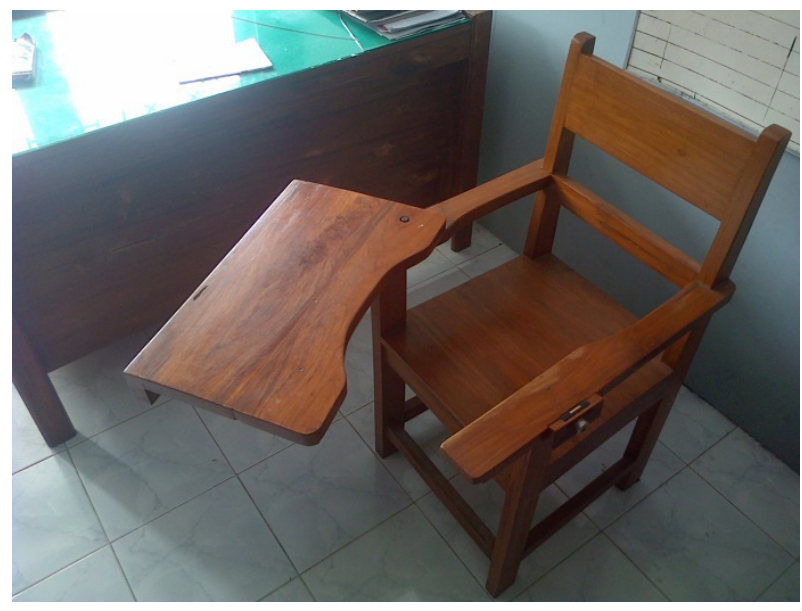

Gambar 18

Kursi dengan meja lipat (Foto: Whisang Geni, 2016)

\begin{tabular}{|c|c|c|}
\hline Panjang & Lebar & Tinggi \\
\hline $80 \mathrm{~cm}$ & $60 \mathrm{~cm}$ & $55 \mathrm{~cm}$ \\
\hline
\end{tabular}

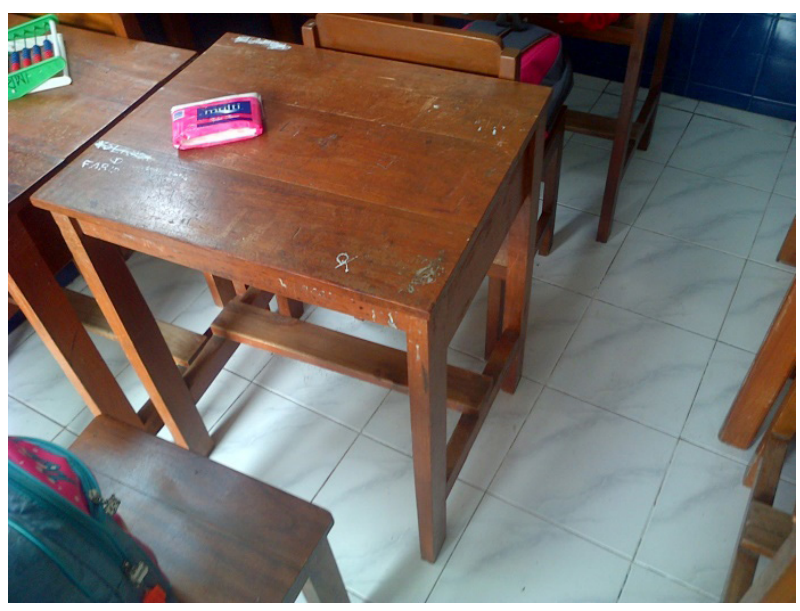

Gambar 19

Set meja kursi biasa

(Foto: Whisang Geni, 2016)

Ukuran Meja Belajar

\begin{tabular}{|l|l|l|}
\hline Panjang & Lebar & Tinggi \\
\hline $70 \mathrm{~cm}$ & $70 \mathrm{~cm}$ & $50 \mathrm{~cm}$ \\
\hline
\end{tabular}

\begin{tabular}{|c|c|c|}
\hline Panjang & Lebar & Tinggi \\
\hline $70 \mathrm{~cm}$ & $50 \mathrm{~cm}$ & $73 \mathrm{~cm}$ \\
\hline
\end{tabular}


Tabel 1:

\section{Permasalahan Aksesibilitas di SDLB Negeri Bendo}

\begin{tabular}{|l|l|}
\hline \multicolumn{1}{|c|}{ AKSES } & \multicolumn{1}{c|}{ KESULITAN } \\
\hline Lapangan & $\begin{array}{l}\text { Terlalu jauh dan tidak } \\
\text { ada railing atau pegangan } \\
\text { tangan. }\end{array}$ \\
\hline $\begin{array}{l}\text { Naikan / ramp } \\
\text { ke teras }\end{array}$ & $\begin{array}{l}\text { Terlalu menanjak dan } \\
\text { tidak ada railing atau } \\
\text { pegangan tangan, lantai } \\
\text { licin. }\end{array}$ \\
\hline Pintu kelas & $\begin{array}{l}\text { Tidak ada pegangan atau } \\
\text { railing, pintu terlalu } \\
\text { sempit. }\end{array}$ \\
\hline Teras kelas & $\begin{array}{l}\text { tidak ada railing atau } \\
\text { pegangan tangan, tidak } \\
\text { ada pagar pembatas. }\end{array}$ \\
\hline $\begin{array}{l}\text { Belokan menuju } \\
\text { lorong toilet }\end{array}$ & $\begin{array}{l}\text { Terlalu sempit, tidak ada } \\
\text { pagar pembatas dan tidak } \\
\text { ada railing. }\end{array}$ \\
\hline Lorong toilet & $\begin{array}{l}\text { Tidak ada pegangan atau } \\
\text { roilling, lantai licin. }\end{array}$ \\
\hline Pintu toilet & $\begin{array}{l}\text { Kurang luas, tidak ada } \\
\text { pegangan atau railing, } \\
\text { lantai licin dan terdapat } \\
\text { level lantai. }\end{array}$ \\
\hline
\end{tabular}

Tabel 2:

\section{Permasalahan Fasilitas Belajar di SDLB}

\section{Negeri Bendo}

\begin{tabular}{|c|l|}
\hline \multicolumn{1}{|c|}{ FASILITAS } & \multicolumn{1}{c|}{ PERMASALAHAN } \\
\hline Meja kursi biasa & $\begin{array}{l}\text { Keluhan beberapa siswa } \\
\text { Tunadaksa yang mera- } \\
\text { sa sakit atau capek saat } \\
\text { menggunakan dalam } \\
\text { jangka waktu yang lama. }\end{array}$ \\
\hline
\end{tabular}

\begin{tabular}{|l|l|}
\hline $\begin{array}{l}\text { Kursi dengan } \\
\text { meja lipat }\end{array}$ & $\begin{array}{l}\text { Siswa terlalu menunduk } \\
\text { saat menulis atau mem- } \\
\text { baca. Siswa tidak bisa } \\
\text { secara mandiri berpindah } \\
\text { dari kursi roda ke meja } \\
\text { lipat, harus dibantu oleh } \\
\text { pengajar. }\end{array}$ \\
\hline $\begin{array}{l}\text { Meja yang diting- } \\
\text { gikan untuk siswa } \\
\text { yang memakai } \\
\text { kursi roda }\end{array}$ & $\begin{array}{l}\text { Siswa terlalu menunduk } \\
\text { saat menulis. }\end{array}$ \\
\hline Papan tulis & $\begin{array}{l}\text { Letak papan tulis terlalu } \\
\text { tinggi, sehingga siswa } \\
\text { dengan kursi roda tidak } \\
\text { dapat menggapai papan } \\
\text { tulis. }\end{array}$ \\
\hline Toilet & $\begin{array}{l}\text { Siswa tidak bisa secara } \\
\text { mandiri beraktivitas di } \\
\text { toilet, karena tidak ada } \\
\text { railing dan ruangan ku- } \\
\text { rang luas. }\end{array}$ \\
\hline
\end{tabular}

Tabel 3:

Analisis Data Ukuran Aksesibilitas dan

Fasilitas di SDLB Negeri Bendo

\begin{tabular}{|l|c|c|c|c|}
\hline Fasilitas Belajar & $\begin{array}{c}\text { Data } \\
\text { Lapa- } \\
\text { ngan }\end{array}$ & $\begin{array}{c}\text { Dinas } \\
\text { PU }\end{array}$ & $\begin{array}{c}\text { J. } \\
\text { Pane- } \\
\text { ro }\end{array}$ & $\begin{array}{c}\text { Ses- } \\
\text { uai } / \\
\text { ti- } \\
\text { dak }\end{array}$ \\
\hline Aksesibilitas & & & & \\
\hline $\begin{array}{l}\text { 1. Lebar jalur } \\
\text { sirkulasi } \\
\text { (lapangan de- } \\
\text { pan) }\end{array}$ & $196 \mathrm{~cm}$ & $\begin{array}{c}200 \\
\mathrm{~cm}\end{array}$ & $\begin{array}{c}230 \\
\mathrm{~cm}\end{array}$ & $\mathrm{x}$ \\
\hline $\begin{array}{l}\text { 2. Ramp } \\
\text { kemiringan }\end{array}$ & $1: 6.2$ & $1: 8-$ & $1: 12-$ & $\mathrm{x}$ \\
\hline $\begin{array}{l}\text { 3. Lebar jalur } \\
\text { sirkulasi } \\
\text { (teras) }\end{array}$ & $180 \mathrm{~cm}$ & $\begin{array}{c}200 \\
\mathrm{~cm}\end{array}$ & $\begin{array}{c}152.4 \\
\mathrm{~cm}\end{array}$ & $\sqrt{ }$ \\
\hline
\end{tabular}




\begin{tabular}{|c|c|c|c|c|}
\hline $\begin{array}{l}\text { 4. Lebar jalur } \\
\text { sirkulasi } \\
\text { (depan toilet) }\end{array}$ & $110 \mathrm{~cm}$ & $\begin{array}{l}200 \\
\mathrm{~cm}\end{array}$ & $\begin{array}{c}152.4 \\
\mathrm{~cm}\end{array}$ & $\sqrt{ }$ \\
\hline $\begin{array}{l}\text { 5. Lebar pintu } \\
\text { kelas }\end{array}$ & $90 \mathrm{~cm}$ & $80 \mathrm{~cm}$ & $\begin{array}{c}81.3 \\
\mathrm{~cm}\end{array}$ & $\sqrt{ }$ \\
\hline $\begin{array}{l}\text { 6. Lebar jalur } \\
\text { sirkulasi } \\
\text { (di dalam kelas) }\end{array}$ & $55 \mathrm{~cm}$ & $\begin{array}{l}110 \\
\mathrm{~cm}\end{array}$ & $\begin{array}{c}91.4 \\
\mathrm{~cm}\end{array}$ & $\mathrm{x}$ \\
\hline $\begin{array}{l}\text { 7. tinggi pegan- } \\
\text { gan tangan } \\
\text { / hand railing }\end{array}$ & - & $65 \mathrm{~cm}$ & & $\mathrm{X}$ \\
\hline $\begin{array}{l}\text { Fasilitas Bela- } \\
\text { jar }\end{array}$ & & & & \\
\hline $\begin{array}{l}\text { 1. set kursi } \\
\text { belajar biasa }\end{array}$ & $\begin{array}{c}40 \times 45 \\
\times 80 \\
\mathrm{~cm}\end{array}$ & - & $\begin{array}{l}36.2 \mathrm{x} \\
41.1 \mathrm{x} \\
70 \mathrm{~cm}\end{array}$ & $\mathrm{X}$ \\
\hline $\begin{array}{l}\text { 2. set meja bela- } \\
\text { jar biasa }\end{array}$ & $\begin{array}{c}70 \times 50 \\
\times 70 \\
\mathrm{~cm}\end{array}$ & - & $\begin{array}{l}76,2 \mathrm{x} \\
45,7 \mathrm{x}\end{array}$ & $\mathrm{X}$ \\
\hline $\begin{array}{l}\text { 3. set kursi } \\
\text { dengan meja } \\
\text { lipat }\end{array}$ & $\begin{array}{c}55 \times 60 \\
\times 80 \\
\mathrm{~cm}\end{array}$ & - & - & - \\
\hline $\begin{array}{l}\text { 4. meja untuk } \\
\text { pengguna } \\
\text { kursi roda }\end{array}$ & $\begin{array}{c}70 \times 50 \\
\times 73 \\
\mathrm{~cm}\end{array}$ & - & $\begin{array}{c}76.2 \mathrm{x} \\
45.7 \mathrm{x} \\
76.2\end{array}$ & $\mathrm{X}$ \\
\hline $\begin{array}{l}\text { 5. ketinggian } \\
\text { papan tulis }\end{array}$ & $\begin{array}{c}100- \\
180 \mathrm{~cm}\end{array}$ & - & $\begin{array}{c}\text { Jang- } \\
\text { kauan } \\
\max \\
137.2 \\
\mathrm{~cm} \\
\end{array}$ & $\sqrt{ }$ \\
\hline $\begin{array}{l}\text { 6. ukuran ruang } \\
\text { toilet }\end{array}$ & $\begin{array}{c}150 \mathrm{x} \\
200 \mathrm{~cm}\end{array}$ & $\begin{array}{c}\text { Min } \\
120 \mathrm{x} \\
200 \\
\mathrm{~cm}\end{array}$ & $\begin{array}{l}\text { Min } \\
91.4 \mathrm{x} \\
182.9 \\
\mathrm{~cm}\end{array}$ & $\sqrt{ }$ \\
\hline $\begin{array}{l}\text { 7. tinggi pegan- } \\
\text { gan tangan } \\
\text { / handrailling } \\
\text { toilet }\end{array}$ & - & $65 \mathrm{~cm}$ & $\begin{array}{c}83.8 \\
\mathrm{~cm}\end{array}$ & $\mathrm{X}$ \\
\hline
\end{tabular}

\section{Kesimpulan}

Setelah melewati berbagai proses dan tahapan penelitian mengenai aksesibilitas dan fasilitas belajar di SDLB Negeri Bendo dapat ditarik beberapa kesimpulan antara lain:

1. Aksesibilitas yang diterapkan saat ini belum memenuhi asas aksesibilitas yang sesuai dengan standar aksesibilitas dan belum mendukung kemandirian siswa, hal ini di karenakan:

a. Jarak menuju kelas yang terlalu jauh

b. Belum ada Railing dan pagar di area sekolah

c. Akses terlalu sempit dan beberapa lantai yang dirasa masih licin

d. Ruang kelas yang terlalu sempit sehingga sirkulasi di dalam kelas terlalu sempit.

2. Fasilitas pendidikan yang diterapkan di SDLB Negeri Bendo membutuhkan beberapa penyesuaian dengan standar fasilitas belajar bagi penyandang tunadaksa, hal ini dikarenakan:

a. Meja kursi yang kurang nyaman bagi siswa Tunadaksa dikarenakan meja terlalu tinggi dan sempit.

b. Papan tulis yang terlalu tinggi dan sulit dijangkau oleh siswa sehingga membutuhkan papan tulis yang bisa di naik turunkan secara mudah.

3. Fasilitas lavatory / toilet yang diterapkan di SDLB Negeri Bendo membutuhkan beberapa penyesuaian dengan standar fasilitas belajar bagi penyandang tunadaksa, hal ini dikarenakan ruang toilet yang kurang lebar untuk akses pemakai kusi roda. 


\section{DAFTAR PUSTAKA}

\section{Buku}

Arianto Sam. Pemngertian Prestasi Belajar. Http://solobaru.blogspot. com/2008/06/pengertian-prestasi-belajar.html. diakses pada 19 September 2016

Arikunto, Suharsimi. Prosedur Penelitiaan Suatu Pendekatan Praktek. Jakarta. Rineka Cipta. 2006

Ferry Firdaus dan Fajar Iswahyudi. "Aksesibilitas Dalam Pelayanan Publik Untuk Masyarakat Dengan Kebutuhan Khusus", Laporan penelitian Pusat Kajian dan Pendidikan dan Pelatihan aparatur III Lembaga Administrasi Negara (PKP2A III LAN), Bogor, 2008.

Dr. Meirinawati, M.AP, “Strategi Dinas Pendidikan Pemerintah Kota Blitar Dalam Meningkatkan Kualitas Pendidikan Kota Blitar", Laporan Penelitian, FISH, UNESA,2016

Handoko." Aksesibilitas Publik Bagi Penyandang Cacat di Indonesia". Skripsi untuk mencapai derajat Sarjana S-1 pada Universitas Pelita Harapan, Tangerang, 2013

H.B.Sutopo.Metode Penelitian Kualitatif, Surakarta,UNS Press,2006

Jonathan Sarwono, Metode Penelitian Kuantitatif dan Kualitatif, Yogyakarta. Graha Ilmu . 2006

Julius Panero, Martin zelnik. Human Dimension \& Interior Space. New York, Billboard Publication. Inc. 1979

Peraturan Menteri Pekerjaan Umum Nomor 30/PRT/M/2006, tentang Pedoman Teknis Fasilitas dan Aksesibilitas pada Bangunan Gedung. dan Lingkungan.
Pusat Bahasa Depdiknas, 2002. Kamus Besar Bahasa Indonesia (Edisi Ketiga). Jakarta, Balai Pustaka.

Sanapiah Faisol, Format-Format Pendidikan, Jakarta. Rajawali Press, 1995

Suminto, Metode Penelitian Sosial dan Pendidikan, Jogjakarta. Andi Offset. 1995

Undang - Undang nomor 19 tahun 2011

Wignjosoebroto, Sritomo. Ergonomi Studi Gerak dan Waktu. Jakarta. Guna Widya. 2003

\section{Sumber Internet :}

www.aliekspres.com/library-furniture-forschools-price.html. Diakses pada 9 desember 2016

www.-blitarkota.go.id, diakses pada 19 September 2016

www.repository.usu.ac.id, diakses pada 12 September 2016. 